\title{
Clear Cell Myomelanocytic Tumor of the Falciform Ligament/Ligamentum Teres
}

National Cancer Institute

\section{Source}

National Cancer Institute. Clear Cell Myomelanocytic Tumor of the Falciform

Ligament/Ligamentum Teres. NCI Thesaurus. Code C38154.

A very rare, usually benign neoplasm with perivascular epithelioid cell differentiation

characterized by the presence of clear spindle cells arranged in fascicles and nests that usually affects young girls. Patients usually present with a painful abdominal mass. 